FACTA UNIVERSITATIS

Series: Law and Politics Vol. 16, No 3, 2018, pp. 173-184

https://doi.org/10.22190/FULP1803173K

Original Scientific Paper

\title{
THE APPLICABILITY OF THE CHARTER OF FUNDAMENTAL RIGHTS IN POLAND
}

\author{
UDC 341.24:342.7(438)
}

\section{Edyta Krzysztofik}

Faculty of Law, Canon Law and Administration, John Paul II Catholic University of Lublin, Poland

\begin{abstract}
The EU system for the protection of fundamental rights had been developing since 1969 until the date of entry into force of the Treaty of Lisbon, which established three areas for the protection of human rights. The first is based on the Charter of Fundamental Rights, the second refers to the general principle, as emphasized by the Court of Justice in its case law in the 1970s. The last area is the future one and it assumes strengthening the protection of fundamental rights within the Council of Europe system by obliging the EU to join the ECHR. The Charter of Fundamental Rights initially had the status of an inter-institutional agreement, which acquired binding force only under the Treaty of Lisbon. Currently, it is a document with normative power equal to primary law. Each of the Member States is bound by the provisions of the Charter within the scope of EU competences and when implementing the EU law. Additionally, Poland and the United Kingdom are parties to Protocol No. 30, which is also treated as primary law. In addition, Poland attached two Declarations to the Treaty of Lisbon. The analysis of the Charter provisions and views of the doctrine clearly indicates that it is not a classic optout clause and the parties cannot release themselves from the obligation to apply the provisions of the Charter. The Declarations, on the other hand, are only political in nature and do not affect the scope of the Charter's application, but they define certain values that are important from the perspective of the Polish legal system.
\end{abstract}

Key words: Protection of fundamental rights, EU law, Charter of Fundamental Rights

\section{GENERAL REMARKS}

One of the distinguishing elements of contemporary international relations is the reference to the concept of personalism, affirmation of the human being and the recognition of dignity as a source of individual rights and freedoms. The tragic war experience made

Received December $12^{\text {th }}, 2018 /$ Accepted December $21^{\text {th }}, 2018$

Corresponding author: Edyta Krzysztofik, PhD, Associate Professor, Department of European Union Law, Faculty of Law, Canon Law and Administration, John Paul II Catholic University of Lublin, Poland E-mail: ekrzyszt@kul.pl 
the international community aware of the need to create effective mechanisms to protect human rights and freedoms at various levels. The processes initiated immediately after the end of World War II have led to the formation of three types of human rights protection systems: intra-state - separate for each country and valid on its territory; international universal, which develops under the auspices of the UN, and regional - characteristic of a specific region of the world (e.g. European, African, inter-American); and transnational connected directly with the emergence and development of the European Union (hereinafter: the EU) (Banaszak 2000: 16). The indicated systems permeate and complement each other, which makes them an increasingly effective form of protection of human rights.

Poland, like other European countries, having completed the process of political transformation that took place in the years 1989-1997, guarantees fundamental rights at various levels. First of all, constitutional guarantees were formed. Secondly, it is a party to the European Convention for the Protection of Human Rights and Fundamental Freedoms (hereinafter: the ECHR) and the International Covenant on Civil and Political Rights, and thus participates in the universal and regional system. Thirdly, as a Member State, it is obliged to guarantee the effectiveness of the EU system for the protection of fundamental rights.

The subject matter of this article is the analysis of one aspect of the system created by the EU and its impact on the protection of fundamental rights in Poland. The considerations will be divided into two parts. The first will be devoted to discussing the structure of protection of human rights in the EU and a detailed analysis of the legal character and structure of the Charter of Fundamental Rights of the European Union (hereinafter: the CFR). The second part will present problems related to the application of the CFR in Poland in connection with the signing of Protocol No. 30.

\section{The MeAning of the Charter of Fundamental Rights In the SyStem OF EU LAW}

The EU system for the protection of fundamental rights had been developing since 1969 until the date of entry into force of the Treaty of Lisbon (hereinafter: TL) (Krzysztofik 2008:33-52, Krzysztofik 2014:63-78), which established three areas for the protection of human rights (Art. 6 TL). ${ }^{1}$ The first is based on the Charter of Fundamental Rights (CFR) of the European Union ${ }^{2}$; the second refers to the general principle which the Court of Justice stressed in its case law in the 1970s. The last area is the future one and it assumes strengthening the protection of fundamental rights within the Council of Europe system by obliging the EU to join the ECHR.

\subsection{The scope of application of the Charter of Fundamental Rights}

The need to create a single catalogue of rights and freedoms protected in the European Union appeared along with the indication of respect for human rights as a general principle

\footnotetext{
${ }^{1}$ See: Treaty of Lisbon (TL) amending the Treaty on European Union (TEU) and the Treaty establishing the European Community, OJ EU 2007 C 306, of. 17.12.2007., available at https://eur-lex.europa.eu/legalcontent/EN/TXT/?uri=celex\%3A12007L\%2FTXT

${ }^{2}$ See: Charter of Fundamental Rights (CFR) of the European Union, OJ EU 2007 C 306; available at https://eurlex.europa.eu/legal-content/EN/TXT/?uri=OJ\%3AC\%3A2007\%3A306\%3ATOC
} 
of EU law in the jurisprudence of the Court of Justice. Work in this area started with the decision to unify the system of protection of human rights, undertaken by the European Council during the Cologne summit and ended with the adoption of a single document - the CFR (Presidency Conclusions, Cologne European Council, 3-4 June 1999). ${ }^{3}$ The Annex to the Conclusions contains general assumptions regarding the provisions of the Charter and the guidelines relating to the body established for its elaboration. It was emphasized that the Charter should contain general principles resulting from the ECHR, constitutional traditions of the Member States, rights granted in the Treaties to citizens of the European Union, as well as economic and social rights arising from the European Social Charter and the Community Charter of Workers Rights and principles stemming from the jurisprudence of the European Court of Justice and the European Court of Human Rights. The next meeting of the European Council took place in Tampere on 15-16 October 1999, where provisions regarding the composition of the body defined as the Convention and the methods of its work were presented in the Presidency Conclusions, specifically in the Annex (Precidency Conclusions, Tampere European Council, 15-16 October 1999). ${ }^{4}$ The Convention adopted the project on 2 October 2000, and it was later adopted by the European Parliament on 14 November 2000, by the European Commission on 6 December 2000, and it was signed and proclaimed in Nice on 7 December 2000 by the Presidents of three Community institutions: the European Parliament, the European Commission and the European Council. Finally, the CFR was signed in Nice in 2000 by three institutions: the Council, the Commission and the Parliament.

The Charter of Fundamental Rights is based on the concept of anthropocentrism, which places man at the centre of regulations (Mik, 2001:66-70). The creators codified the rights, freedoms and principles that had various sources: the European Convention on Human Rights, the European Social Charter, constitutional traditions common to all Member States, as well as the provisions of the Founding Treaties (Arnold, 2002: 38).

In the initial period, the Nice Charter was not binding. During the European Council summit in Nice, it was emphasized that it is only a "declaration of European morality" (Muszyński, 2009: 56). The legal character of the CFR was ambiguous. The literature assumes that it was an inter-institutional agreement (Muszyński, et al., 2009: 58). There is no doubt, however, that it had a huge influence on the functioning of EU institutions. As an example, the position presented by the Commission immediately after the proclamation of the CFR should be indicated, in which the Commission emphasized that it would treat the CFR as a binding act. It consistently studied legislative proposals in terms of compliance with the Charter's provisions. A similar position was taken by the European Parliament which, based on Article 34 of the regulations, controlled legislative projects dealing with the provisions of the CFR (Wieruszewski, 2008: 52-53). However, the position of the Court of Justice of the European Union was the most important in defining the place of the CFR in the system of EU law. The first spokesman was Advocate General M. Damaso Ruiz Jarabo Colomer, who stressed that "it does not have any autonomous binding effect because it does not have any legal force of its own". However, its content is based on the Member States' values which, by virtue of the CJEU jurisprudence, have been recognized as general

\footnotetext{
${ }^{3}$ See: Presidency conclusions, Cologne European Council, 3-4 June 1999, available at http://ue.eu.int/ueDocs/cms_Data/docs/pressData/en/ec/kolnen.htm

${ }^{4}$ See: Precidency conclusions, Tampere European Council, 15-16 October 1999; available at http://ue.eu.int/ueDocs/cms_Data/docs/pressData/en/ec/00200-r1.en9.htm
} 
principles of EU law. He added that the CFR "Should be treated as a substance of a common European acquis in the area of fundamental rights. It does not create a new law, but it codifies existing "unwritten Community rules" known in universal international law as general principles of rights (...) The Charter does not become legally binding, but legally significant" (Muszyński, et al., 2009: 56-57).

This stance was also shared by the CJEU, which stressed in one of its judgments that "While the Charter is not a legally binding instrument, the Community legislature did, however, acknowledge its importance by stating, in the second recital in the preamble to the Directive, that the Directive observes the principles recognised not only by Article 8 of the ECHR but also in the Charter. Furthermore, the principal aim of the Charter, as is apparent from its preamble, is to reaffirm 'rights as they result, in particular, from the constitutional traditions and international obligations common to the Member States, the Treaty on European Union, the Community Treaties, the [ECHR], the Social Charters adopted by the Community and by the Council of Europe and the case-law of the Court ... and of the European Court of Human Rights." 5 According to the CJEU, the CFR's applicability is dictated by the fact that it is consistent with the standards of protection of human rights, which were protected in the EU on the basis of the general principle.

Legal actions aimed at giving binding force to the CFR were taken during the work on the Treaty establishing a Constitution for Europe. A general reference to its provisions was made in Article I-7 of the first part and its test was included in part II as an integral element of the Treaty. ${ }^{6}$ Due to the fact that the Treaty was not ratified by all Member States, the current reforms were adopted under the Treaty of Lisbon. By virtue of the provisions of Article 6 par. 1 TEU, the position of the CFR in the system of EU law was clarified.

The Treaty of Lisbon gave the CFR binding force equal to primary law. In the provisions of Article 6 par. 1 TEU, it gave the CFR normative power equal to primary law. Thus, it has become a source of law with the highest normative power in the system of sources of EU law. The consequence of this is the direct effectiveness of the CFR, the possibility of relying on its provisions before national courts and the CJEU (of course, provided they are rights which are directly effective and only in the area of EU law), and an indirect effect in interpreting the provisions of EU and national law in the scope of the functioning of EU law. In addition, it was subject to the principle of primacy in the event of a conflict with rules of national law within the scope of EU law and provided that the fundamental rights were properly invoked (Wyrozumska, 2008: 83-84).

The analysis of the scope of application of the CFR should start from the last chapter and the provisions of Articles 51-54 CFR, (especially Article 51 CFR) and Article 6 par. 1 TEU, as well as paragraph 2 of Declaration No. 1 attached to the Treaty of Lisbon concerning the Charter of Fundamental Rights of the European Union and explanations attached to the CFR (Article 51). Wyrozumska emphasizes that "the use of the Charter was subject to conditions specified in the Charter itself, then repeated in the Treaty of Lisbon in Article 6 par. 1 and strengthened politically by the Declaration of the Conference." (Wyrozumska, et al. 2008: 86).

\footnotetext{
${ }^{5}$ Case 540/03 European Parliament v. Council of the European Union, of 27 June 2006, available at https://eur-lex.europa.eu/legal-content/EN/TXT/?uri=CELEX\%3A62003CJ0540

${ }^{6}$ See: Treaty establishing a Constitution for Europe, OJ EU C 310, of 16 December 2004, available at https://eur-lex.europa.eu/legal-content/EN/TXT/?uri=CELEX\%3AC2004\%2F310\%2F01
} 
The basic condition expressed in the indicated provisions is the limitation of the application of the CFR only to the scope of application of EU law. It was clearly emphasized that the catalogue of rights, freedoms and principles included in the CFR does not extend the scope of application of EU law beyond EU competences, nor its tasks, nor does it change the competences and tasks defined in the Treaties (Article 51 CFR). Thus, the EU takes action in accordance with the principle of competences entrusted to it and only within the limits of the competences delegated to it by the Member States, contained in the TEU and the TFEU; the principle of conferral was expressed in Article 5 par. 2 TEU. At the same time, the Treaty of Lisbon specified the types of competences by dividing them to exclusive (Article 3 TFEU), shared (Article 4 TFEU) and coordination competences (Article 6 TFEU). EU institutions, including the CJEU, are fully bound by this principle. Thus, the CFR does not bind the Member States to the full extent of the application of national law, but it is binding in those areas which fall within the competence of the EU; District Court in Częstochowa, IV Division of Labour and Social Insurance in Częstochowa, on 13 December 2013 (Case IV U1470 / 12) directed five questions regarding the retirement provision of the officers of Police, Internal Security Agency, Intelligence Agency, Military Counter-intelligence Service, Military Intelligence Service, Central Anti-corruption Bureau, Border Guard, Government Protection Bureau, State Fire Service and Prison Service and their families, and compliance with principles of respect for human dignity, the rule of law, equality, non-discrimination and the right to a fair trial. The Court of Justice found that it was not competent to answer these questions. In the argumentation, the CJEU emphasized that the CFR only binds Member States when they apply EU law, and that its provisions do not extend the scope of EU competences. In the CJEU's view, the Polish Court has not sufficiently shown that the Act of 2009 falls within the scope of application of EU law or is its direct application. The key judgment in the analysis of the provisions of Article 51 par. 1 CFR is the judgment of the CJEU in case C 617/10 ̊klagaren v. Hans Akerrberg Fransson (EU:C; 2013: 105), where the CJEU emphasized that "[...] the fundamental rights guaranteed in the legal order of the European Union are applicable in all situations governed by European Union law, but not outside such situations. In this respect the Court has already observed that it has no power to examine the compatibility with the Charter of national legislation lying outside the scope of European Union law. [...]. Since the fundamental rights guaranteed by the Charter must therefore be complied with where national legislation falls within the scope of European Union law, situations cannot exist which are covered in that way by European Union law without those fundamental rights being applicable. The applicability of European Union law entails applicability of the fundamental rights guaranteed by the Charter.",

The obligated entities are the EU, EU institutions and EU organizational units respecting the principle of subsidiarity, and the Member States, but only when they implement EU law. This condition means that the CFR binds the States only in the implementation of EU law and not in the entire sphere of national law.

The indicated provisions are strengthened by Article 51 par. 2 CFR, which emphasizes that "The Charter does not extend the field of application of Union law beyond the powers of the Union or establish any new power or task for the Union, or modify powers and tasks as defined in the Treaties." The indicated wording should be understood as a legally

\footnotetext{
${ }^{7}$ C 617/10 Åklagaren v. Hans Åkerrberg Fransson, EU:C; 2013:105, of 26 February 2013, available at. https://eur-lex.europa.eu/legal-content/EN/ALL/?uri=ecli:ECLI:EU:C:2013:105
} 
binding principle of interpretation and application of EU law (Wróbel, 2013: 1343). The interpretation should be that the interpretation of EU law in relation to the CFR or in accordance with its provisions should not lead to the extension of EU competences (Wróbel, et al. 2013: 1343).

Another issue related to the application of the CFR is the diversity of the rights contained therein. The Charter itself indicates rights, freedoms and principles. The rights may be directly effective, while the freedoms are specific program standards that require implementing acts and can be used to interpret implementing acts or to control their validity. The Charter of Fundamental Rights does not specify which regulations contain rights and which contain principles. In addition, explanations to the CFR indicate provisions that in some elements include both principles and rights; in accordance with the views expressed in the literature on the subject, rights were regulated in: Art. 2, Art. 4-8, Art. 9-14, Art. 16-19, Art. 21, Art. 39-40, Art. 42-48, Art. 50. Principles were regulated in: Art. 20, Art. 25-26, Art. 35-38, whereas the regulations that combine rights and principles are regulated in: Art. 3, Art. 15, Art. 23-24, Art. 27-33, Art. 34, Art. 41, Art. 49 (Kamiński 2009: 42; Wróbel 2009: 44).

The last matter which should be given special attention is the provisions of Article 52 par. 2-4 CFR, which contain interpretative guidelines. The CFR contains the rights, freedoms and principles that derive from the ECHR, the Founding Treaties and the constitutional traditions common to all Member States. In addition, as indicated, the explanations to the Charter specify what the source of a given provision is. Therefore, the CFR provisions should be interpreted in accordance with the source of origin, i.e. the ECtHR jurisprudence, the CJEU case law or the constitutional traditions common to all Member States.

When analysing the case law of Polish courts, particular attention should be paid to the problem of examining the scope of the Charter. Many times courts omit the reference to the general provisions of the Charter and do not articulate argumentation to determine whether it is possible to invoke its provisions on the subject of the proceedings (Wróblewski, 2015:18). Wróblewski emphasizes that administrative courts very often refer to the provisions of the CFR primarily in the context of the principle of respecting the right to good administration. However, the problem is that in none of the judgments have the courts considered whether or not the CFR's stance is possible in a given case. In addition, they did not interpret the provisions of Article 41 CFR which, according to the literal wording, provides that the right to good administration applies to the institutions, bodies and agencies of the Union (C 604/12, EU: C; 2013:714). ${ }^{8}$ Similar observations concern judgments of common courts. They use the CFR's provisions without analysing the scope of its application. In contrast, the Supreme Administrative Court and the Supreme Court sporadically refer to the CFR, but they apply it correctly in the context of EU law. It is worth recalling the position of the Supreme Administrative Court, which drew attention to the relationship between the CFR provisions and the existing norms of EU law. It emphasized that "the Charter of Fundamental Rights, as a primary law, is part of the legal order of the European Union, but the allegation of violation of the provisions of this Charter can only be raised if EU law other than the Charter applies or should apply. Thus,

\footnotetext{
${ }^{8}$ C 604/12 H. N. v. Minister for Justice, Equality and Law Reform and Others, EU: C:2013:714, of 7 Nov. 2013, available at https://eur-lex.europa.eu/legalcontent/EN/TXT/?uri=ecli\%3AECLI\%3AEU\%3AC\%3A2013\%3A714
} 
the allegation of violation of the provisions of the CFR cannot be independent grounds for the complaint for declaring the Supreme Administrative Court's decisions contrary to law, because the Charter is applicable only if other European Union law may apply in the case, and the indication of these provisions is required in a complaint of non-compliance of the Supreme Administrative Court rulings specified in art. 285 e $\$ 1$ point 3 p.p.s.a. (law on proceedings before administrative courts). Failure to do so results in the complaint being rejected, pursuant to art. 285 h $\$ 1$ p.p.s.a (NSA Decision of 22 August 2014 r. (II ONP 4/14), LEX nr. 1584120)” (Wróblewski, et al. 2015: 18-19 and 21-22).

\section{THE IMPACT OF THE POLISH-BRITISH PROTOCOL ON THE APPLICATION OF THE CHARTER of FundAMENTAL RightS IN POLAND AND THE UNITED KINGDOM.}

When considering the problem of using the CFR, reference should also be made to the Polish-British Protocol (Protocol No. 30 on the Application of the Charter of Fundamental Rights of the European Union to Poland and to the United Kingdom) ${ }^{9}$ attached to the Treaty of Lisbon (hereinafter: the TL).

The content of the Protocol was essentially negotiated by the United Kingdom, and Poland joined it in the final phase of the negotiations (Wieruszewski, 2008: 56-59; Wyrozumska, 2007: 59). It is assumed in the literature that it is an international agreement that is at the same time an integral part of the TL. Therefore, after the TL entered into force, this agreement gained the power of primary law (Wyrozumska, 2008: 32).

The analysis of the provisions of the Preamble to the Protocol indicates that its purpose is to specify to what extent and how the CFR will be applied in Poland and the United Kingdom. Therefore, it cannot be an opt-out clause in the classic sense (Schütze, 2012: 441). It seems, however, that the aims of the state parties were different; it should be emphasized here that, throughout the work on the CFR, the United Kingdom was against making it binding and stressed that it cannot be the beginning of the process of shaping of the European constitution or become a new standard in the currently binding legal system (Skrzydło, 2015: 25-29). They assumed that the Protocol would result in limiting the use of the CFR in their legal systems. This is confirmed by the position of a British judge who emphasized in one of the judgements that he was "surprised that the legal basis was invoked by the plaintiff, i.e. that the Charter of Fundamental Rights applies in the case, despite the fact that the British Government - as well as Polish - secured a derogation during the negotiations on the Treaty of Lisbon. Meanwhile, despite the efforts of the representatives in Lisbon, the Charter is apparently a part of British law." (Skrzydło, 2015: 26).

When considering the effect of the Protocol, one should first and foremost make literal interpretations of its provisions. It indicates that, first, the CFR is applied in Poland and the United Kingdom only when they implement EU law. According to Article 1 CFR, the Protocol does not extend the ability of the CJEU or the national courts (in Poland and in the United Kingdom) to recognize that national provisions violate the rights or principles contained in the CFR. In addition, pursuant to Article 2, provisions of Title IV are justiciable solely in the situation and to the extent in which they result from the provisions in Poland or in the United Kingdom. There is no doubt that the indicated provisions

\footnotetext{
${ }^{9}$ See: Protocol No. 30 on the Application of the Charter of Fundamental Rights of the European Union to Poland and to the United Kingdom, OJ EU C 326, of 26 October 2012, available at https://eurlex.europa.eu/legal-content/EN/TXT/?uri=CELEX\%3A12012E\%2FPRO\%2F30
} 
correspond with the provisions of Article 51 CFR, which has been discussed in more detail above.

It should be noted, however, that the CFR contains rights and principles that come from three different sources. As has been indicated, these sources are the constitutional traditions common to all Member States, the ECHR and the Founding Treaties. In principle, it should be assumed that the CFR confirms the already existing rights and principles that are protected in the Member States, because they are consistent with each State's constitutional traditions; in this respect, the CFR, using common constitutional traditions as the basis, may be the minimum standard of protection, while states can retain wider protection. (Cf.: Position of the CJEU in the case of Omega ${ }^{10}$; the subject matter of the analysis was the prohibition of betting in the "Playing at killing" game. German authorities referred to the premise of public order indicating that the game infringes the constitutional principle of protection of human dignity. The discussed decision does not refer to the provisions of the CFR, because the German level of protection exceeded the EU standard.)

The second indicated source is the ECHR. Poland is a party to the Convention and the protection of these rights and principles results from legal and international obligations. On the other hand, the rights and principles derived from the Founding Treaties were protected at the EU level even before the adoption of the CFR. From the Polish perspective, it has been a party to the European Convention for the Protection of Human Rights and Fundamental Freedoms since 1992 (the Convention was drafted on 4 November 1950 in Rome, ratified by Poland in 1993, and published in Dz. U. 1993.61.284), joined the EU in 2004 (by The Treaty of Accession to the EU of 16 April 2003, OJ EU, L 236, 23 September 2003, published in Poland in Dz. U. 2004.90.864), ${ }^{11}$ so that EU law has been in force in the Polish legal system since 1 May 2004. Moreover, the Polish Constitution was based on common European values (Lętowska, 2005: 3ff). Therefore, from this perspective, it seems that the CFR provisions do not pose a threat to the Polish legal system.

Poland also added two unilateral declarations to the TL relating to the CFR's applicability. Of course, the legal nature of the declarations is different from the CFR. They are not binding, but they are political declarations of the state. The first of them, Declaration No. 61, refers to values that are very important and especially prized in Poland. It stipulates that "The Charter does not affect in any way the right of Member States to legislate in the sphere of public morality, family law, as well as the protection of human dignity and respect for human physical and moral integrity." The second, Declaration No. 62, refers indirectly to the Protocol because it takes the same scope of provisions. According to its wording, "Poland declares that, having regard to the tradition of social movement of 'Solidarity' and its significant contribution to the struggle for social and labour rights, it fully respects social and labour rights, as established by European Union law, and in particular those reaffirmed in Title IV of the Charter of Fundamental Rights of the European Union." It seems that the Polish assumptions regarding the role of the Protocol should be interpreted together with the Declarations. The Polish government sought to

\footnotetext{
${ }^{10} \mathrm{C}$ - 36/02 Omega Spielhallen- und Automatenaufstellungs-GmbH v. Oberbürgermeisterin der Bundesstadt Bonn 1, ECR 2004, p. I-9609.

${ }^{11}$ See: The Treaty of Accession of the Czech Republic, the Republic of Estonia, the Republic of Cyprus, the Republic of Latvia, the Republic of Lithuania, the Republic of Hungary, the Republic of Malta, the Republic of Poland, the Republic of Slovenia and the Slovak Republic to the European Union, Athens, 16 April 2003, OJ EU, L 236, 23 September 2003, published in Poland in Dz. U. 2004.90.864, available at https://eur-lex.europa.eu/legal-content/EN/TXT/?uri=CELEX:12003T/
} 
create instruments for the protection of the values protected in the Polish legal system, i.e. human dignity, public morality, but also employee rights (Barcz, 2008: 101-106). Poland's fears were mostly related to the future situation, when the CJEU, through its broad interpretation of the provisions of the CFR, would violate the protected values (Sieniow, 2012: 106). In this context, it is worth paying attention to the position of Constitutional Courts in relation to the position in the previously mentioned Aklagaren case on the scope of application of the CFR in the legal systems of the Member States. The Federal Constitutional Court stressed that "if it were found that the CJEU was operating ultra vires, undermining the constitutional bases of states by unjustifiably extending the scope of the Charter, EU law must give way to constitutional regulations." On the other hand, the Supreme Court of the United Kingdom found that "there are also boundaries in the unwritten constitution of the United Kingdom that the Court of Justice cannot transgress when interpreting EU law: under no circumstances can the British courts rule on the legality of parliamentary procedures or derogate from fundamental constitutional principles." (Skrzydło 2015:28).

The final stance regarding the applicability of the CFR in the legal systems of Poland and the United Kingdom was taken by the Court of Justice in case C 411/10. The CJEU took the view that "[...] Protocol No 30 [...] does not call into question the applicability of the Charter in the United Kingdom or in Poland, a position which is confirmed by the recitals in the preamble to that protocol. [...] the Charter must be applied and interpreted by the courts of Poland and of the United Kingdom strictly in accordance with the explanations referred to in Article 1 of the protocol. In addition, according to the sixth recital in the preamble to that protocol, the Charter reaffirms the rights, freedoms and principles recognised in the Union, and makes those rights more visible, but does not create new rights or principles. In those circumstances, Article 1(1) of Protocol (No 30) explains Article 51 of the Charter with regard to its field of application and is not intended to exempt the Republic of Poland or the United Kingdom from the duty to comply with the provisions of the Charter, or to prevent a court of one of those Member States from ensuring compliance with those provisions." 12 The cited position of the CJEU may indicate that in practice the discussed Protocol will have little relevance in areas already regulated by EU law.

\section{FINAL REMARKS}

The EU system for the protection of fundamental rights was the beginning of a new dimension of European integration aimed at establishing European constitutional identity based on common values. An individual who, in the initial period of integration, could not benefit from protection of fundamental rights and freedoms acquired a new status. The Treaty of Lisbon not only confirms this state of affairs but additionally strengthens their protection by establishing three levels of protection. Making the Charter of Fundamental Rights binding increased the transparency of protection standards. In accordance with horizontal clauses, Member States are bound by its provisions in every situation where they apply EU law or when a given situation falls within the scope of EU competence. This issue was widely interpreted at the EU and national level.

\footnotetext{
${ }^{12}$ C 411/10 Court of Justice case, N. S. $v$ Secretary of State for the Home Department and M. E. and Others (C493/10) v Refugee Applications Commissioner and Minister for Justice, Equality and Law Reform, 21 December 2011; available at http://curia.europa.eu/juris/liste.jsf?num=C-411/10
} 
A separate issue is the binding effect given to the CFR by two countries, Poland and the United Kingdom, which signed Protocol No. 30. The structure of the document corresponds to the provisions of Article 51 of the CFR and thus does not constitute an instrument limiting its effectiveness, but has an interpretive value. However, the signing of the Protocol caused many problems for entities applying the CFR.

The analysis of the jurisprudence of Polish courts indicates that they readily refer to the provisions of the CFR. This is most visible in the judgments of administrative courts, which have repeatedly referred to the right to good administration. A serious failure, however, is the omission of the most important element or examining the scope of applicability of the CFR. The exceptions in this respect are the judgments of the Supreme Court and the Supreme Administrative Court. There is no doubt that Protocol No. 30 has caused problems and is still a problematic issue. Due to the ambiguous position of the doctrine in the initial period of the CFR's existence, the courts try not to refer to the provisions of Title IV of the CFR. This is obviously incorrect because, as shown, the CFR is a fully binding document in the Polish legal system.

\section{REFERENCES}

Arnold R. (2002), Karta Praw Zasadniczych Unii Europejskiej, Państwo i Prawo 2002, vol. 3

Banaszak B.,(2003), Zagadnienia podstawowe. Terminologia/ Banaszak B., Bisztyga A., Complak K., Jabłoński M., Wieruszewski K., Wojtowicz K (ed.), Ochrony praw człowieka, Zakamycze 2003

Barcz J., (2008), Ochrona praw podstawowych w Unii Europejskiej, Warszawa 2008

Kamiński I.C., (2009), Karta Praw Podstawowych jako połaczenie praw i zasad - strukturalna wada czy szansa?/ Wróbel A., (ed.), Karta Praw Podstawowych w europejskim i krajowym porządku prawnym, Wróbel A., Warszawa 2009

Krzysztofik E., (2008), Ewolucja wspólnotowego systemu ochrony praw podstawowych, Studia Prawnicze KUL 2 (34) 2008

Krzysztofik E., (2014), Ochrona praw podstawowych w Unii Europejskiej po Traktacie z Lizbony, Roczniki Administracji i Prawa rok XIV

Łętowska E., 2005, Multicentryczność współczesnego systemu prawa i jej konsekwencje, Państwo i Prawo, 2005 , no. 4

Mik C., (2001), Karta Praw Podstawowych Unii Europejskiej, zagadnienia podstawowe/ Podraza A., (ed.) Traktat Nicejski, Lublin 2001

Muszyński M., (2009), Polska Karta Praw Podstawowych po Traktacie Lizbońskim. Charakter prawny i granice związania, Przegląd Sejmowy, 1 (90)/2009

Schütze R., 2012, European constitutional law, Cambridge

Sieniow T., (2012), Ochrona praw i wolności jednostek w Unii Europejskiej, Kuś A. (ed.) Prawo instytucjonalne Unii Europejskiej w zarysie, Lublin 2012

Skrzydło J. (2015), Karta Praw Podstawowych UE w praktyce brytyjskiej, Europejski Przegląd Sądowy 10/ 2015, Walters Kluwer Polska

Wieruszewski R, (2008), Rola i znaczenie Karty Praw Podstawowych dla ochrony praw człowieka, Przegląd sejmowy, 2(85) 2008

Wieruszewski R., (2008), Rola i znaczenie Karty Praw Podstawowych Unii Europejskiej dla ochrony praw człowieka, Przegląd Sejmowy 2(85)/2008

Wróbel A., (2013), Objaśnienia do art. 51 KPP/ Wróbel A. (ed.), Karta Praw Podstawowych unii Europejskiej, Komentarz, Warszawa 2013

Wróblewski M., (2015), Karta Praw Podstawowych w polskim sądownictwie - problemy i wyzwania, Krajowa Rada Sadownicza 2/2015

Wyrozumska A, (2007), Karta Praw Podstawowych - polskie obiekcje, Sprawy Międzynarodowe 2007, no. 4

Wyrozumska A., (2008), Inkorporacja Karty Praw Podstawowych do UE: status Karty w prawie UE, zakres obowiązywania i stosowania, główne problemy interpretacyjne z uwzględnieniem stanowiska polskiego, Barcz J. (ed.) Ochrona praw podstawowych w Unii Europejskiej, Warszawa 2008 
Wyrozumska A., (2008), Znaczenie prawne zmiany statusu Karty Praw Podstawowych Unii Europejskiej w Traktacie Lizbońskim oraz Protokołu Polsko-Brytyjskiego, Przegląd Sejmowy 2 (85) 2008

\section{LEGAL DOCUMENTS}

Charter of Fundamental Rights of the European Union (CFR), OJ EU 2007 C 306; available at https://eurlex.europa.eu/legal-content/EN/TXT/?uri=OJ\%3AC\%3A2007\%3A306\%3ATOC

Presidency conclusions, Cologne European Council, 3-4 June 1999, available at http://ue.eu.int/ueDocs/ cms_Data/docs/pressData/en/ec/kolnen.htm

Precidency conclusions, Tampere European Council, 15-16 October 1999; available at http://ue.eu.int/ueDocs/ cms_Data/docs/pressData/en/ec/00200-r1.en9.htm

Protocol No. 30 on the Application of the Charter of Fundamental Rights of the European Union to Poland and to the United Kingdom, OJ EU C 326, of 26 October 2012, https://eur-lex.europa.eu/legal-content/EN/ TXT/?uri=CELEX\%3A12012E\%2FPRO\%2F30

Treaty of Accession of the Czech Republic, the Republic of Estonia, the Republic of Cyprus, the Republic of Latvia, the Republic of Lithuania, the Republic of Hungary, the Republic of Malta, the Republic of Poland, the Republic of Slovenia and the Slovak Republic to the European Union, Athens, 16 April 2003, OJ EU, L 236, 23 Sept. 2003, https://eur-lex.europa.eu/legal-content/EN/TXT/?uri=CELEX:12003T/

Treaty establishing a Constitution for Europe, OJ EU C 310, of 16 Dec. 2004, available at https://eurlex.europa.eu/legal-content/EN/TXT/?uri=CELEX\%3AC2004\%2F310\%2F01

Treaty of Lisbon (TL) amending the Treaty on European Union and the Treaty establishing the European Community, OJ EU 2007 C 306; of. 17.12.2007, available at https://eur-lex.europa.eu/legalcontent/EN/TXT/?uri=celex\%3A12007L\%2FTXT

\section{CASE LaW}

Case 540/03 European Parliament v. Council of the European Union, 27 June 2006, available at https://eurlex.europa.eu/legal-content/EN/TXT/?uri=CELEX\%3A62003CJ0540

C-617/10 Åklagaren v. Hans Åkerrberg Fransson, EU: C; 2013:105. available at: https://eurlex.europa.eu/legal-content/EN/ALL/?uri=ecli:ECLI:EU:C:2013:105

C 604/12 H. N. v. Minister for Justice, Equality and Law Reform and Others, EU: C:2013:714, https://eurlex.europa.eu/legal-content/EN/TXT/?uri=ecli\%3AECLI\%3AEU\%3AC\%3A2013\%3A714

C-411/10 Court of Justice case, N. S.(C-411/10) v Secretary of State for the Home Departmentt and M. E. and Others C-493/10) v Refugee Applications Commissioner and Minister for Justice, Equality and Law Reform, 21.Dec.2011; http://curia.europa.eu/juris/liste.jsf?num=C-411/10

C - 36/02 Omega Spielhallen- und Automatenaufstellungs-GmbH v. Oberbürgermeisterin der Bundesstadt Bonn 1, ECR 2004, p. I-9609. 


\section{PRIMENA POVELJE O OSNOVNIM PRAVIMA U POLJSKOJ}

Sistem zaštite osnovnih prava Evropske unije razvijao se od 1969. godine do dana stupanja na snagu Lisabonskog ugovora, koji je uspostavio tri oblasti za zaštitu ljudskih prava. Prva oblast se zasniva na Povelji o osnovnim pravima; druga se odnosi na opšte načelo koji je Sud pravde proklamovao u svojoj sudskoj praksi 1970-ih godina. Poslednja oblast odnosi se na jačanja zaštite osnovnih prava u sistemu Saveta Evrope u budućnosti, koja podrazumeva obavezuju EU da pristupi Evropskoj konvenciji o ljudskim pravima. Povelja o osnovnim pravima je na početku imala status međuinstitucionalnog sporazuma, koji je dobio obavezujuć snagu tek na osnovu Lisabonskog ugovora. Ovaj dokument trenutno ima_normativnu snagu primarnog izvora prava. Odredbe Povelje obavezuju svaku državu članicu na primenu zakona EU u okviru nadležnosti EU. Pored toga, Poljska i Ujedinjeno Kraljevstvo su države ugovornice Protokola br. 30, koji se takođe tretira kao primarni izvor prava. Osim toga, Poljska je pridodala dve deklaracije Lisabonskom ugovoru. Analiza odredbi Povelje o osnovnim pravila i stavova u doktrini jasno ukazuje na to da se ne radi o klasičnoj opt-out klauzuli, pa se države ugovornice ne mogu osloboditi obaveze primene odredaba Povelje o osnovnim pravima. Sa druge strane, s obzirom da su deklaracije dokumenti isključivo političke prirode, one ne utiču na obim primene ove Povelje, ali definišu određene vrednosti koje su važne iz perspektive poljskog pravnog sistema.

Ključne reči: zaštita osnovnih prava, pravo Evropske unije, Povelja o osnovnim pravima 